УДК: 902.3

\title{
Сергій Тараненко,
}

кандидат історичних наук,

завідувач науково-дослідним сектором археологї

Начіонального Кисво-Печерського

історико-культурного заповідника,

e-mail: taransun@ukr.net

\section{Сергій Горбаненко,}

кандидат історичних наук,

старший науковий співробітник Інституту археологї НАН

України,

e-mail: gorbanenko@gmail.com

\section{Олександр Ковальчук,}

кандидат біологічних наук,

науковий співробітник

Начіонального науково-природничого музею НАН України, e-mail: biologiest@ukr.net

\section{Леонід Горобець,}

кандидат біологічних наук,

асистент кафедри екології й охорони навколишнього середовища

Начіонального університету ім. Тараса Шевченка;

старший науковий співробітник

Національного науково-природничого музею НАН України, e-mail: ornitologist@gmail.com

\section{Марина Сергсєва,}

кандидат історичних наук,

старший науковий співробітник

Інституту археології НАН України,

e-mail: mar.sergeyeva@gmail.com

\section{Павло Пучков,}

кандидат біологічних наук,

зберігач фондів відділу палеонтології

Національного науково-природничого музею НАН Украӥни,

e-mail: reduvion@mail.ru

\section{КОМПЛЕКСНІ БІОАРХЕОЛОГІЧНІ ДОСЛІДЖЕННЯ МАТЕРІАЛІВ 3 РОЗКОПОК НА ТЕРИТОРІЇ КИЄВО-ПЕЧЕРСЬКОГО ЗАПОВІДНИКА У 2016 p.}

У публікації оприлюднено результати комплексних біоархеологічних визначень з археологічних досліджень 2016 р. споруди 1 розкопу 1 Національного Києво-Печерського історико-культурного заповідника.

Ключові слова: Києво-Печерська лавра, флотачія, промивання, палеоботаніка, археозоологія. го Києво-Печерського історико-культурного заповідника під керівництвом С.П. Тараненка проведено стаціонарні 
${ }^{1}$ Балакін, С. А., Зажигалов, О. В., Фінадоріна, Д. В. (2014/[б. н.]). Звіт про результати археологічних досліджень на території Національного Києво-Печерського історико-культурного заповідника у 2014 р. Науковий архів Інституту археології Національної академії наук Украӥни (далі - НА ІА НАН України).

2 Тараненко, С. П., Мисько, Ю. В., Зажигалов, О. В., Балакін, С. А. (2016). Створення археологічної карти Національного Києво-Печерського історико-культурного заповідника.

Церква-наука-суспільство питання взаємодіï: Матеріали Чотирнадиятої Міжнар. наук. конф. (25 травня - 3 червня 2016 р.). Киї, 30-32.

Рис. 1. Фрагмент археологічної карти КПЛ - територія Митрополичого саду (автор С. П. Тараненко). Кольорова гама відповідає хронології досліджених пам'яток: оранжевий ранній залізний вік; червоний - Київська Русь; синій - післямонголський час; зелений - Новий час; жовтий - дослідження на території Митрополичого саду Києво-Печерської лаври. Ця територія має не тільки цікаву історію, але й достатньо високий рівень археологічного вивчення, розпочатого в середині XIX ст., яке, з певними перервами продовжується дотепер.. Передусім йдеться про роботи 1951, 1961, 1987-88, 1989, 1993, 2002, 2011 i 2014 pp. У результаті багаторічних досліджень тут розкрито близько $650 \mathrm{M}^{2}$ і встановлено наявність на зазначеній ділянці Верхньої лаври трьох основних культурно-хронологічних горизонтів, а саме пам'яток скіфського, давньоруського та пізньосередньовічного часу ${ }^{1}$. Аналіз археологічної ситуації території Митрополичого саду відображений на археологічній карті заповідника (рис. 1)2. Саме вона стала підгрунтям для проведення робіт у 2016 p.

Розкоп 1 був розбитий у південно-західному куті Митрополичого саду КПЛ. Східна стінка розкопу розміщалася на відстані 1,0-1,08 м від східної стіни Мазепинських мурів; південно-західний кут розкопу - 4,16 м від південної стіни Мазепинських мурів; південно-східний кут $-5,08$ м від південної стіни Мазепинських мурів (рис. 2). Розкоп орієнтований стінами за сторонами світу, його розміри $3 \times 6 \mathrm{м}$ (рис. 3 ).

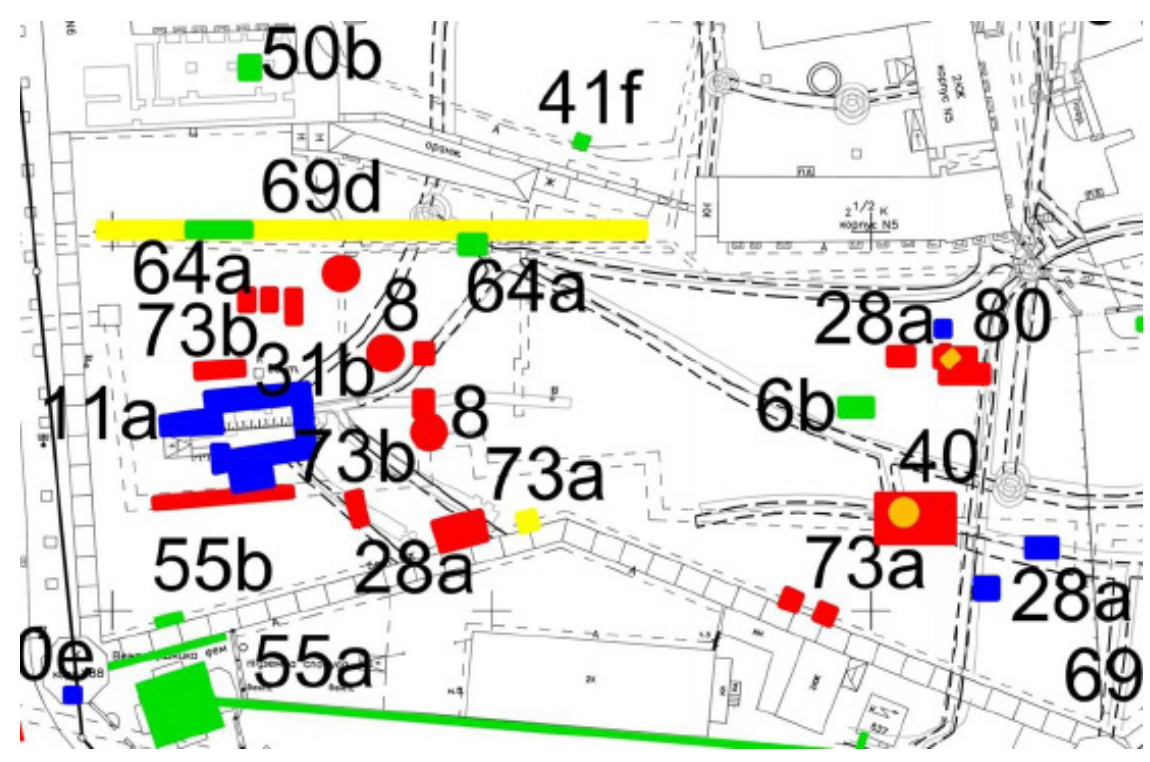

3 рівня близько 2 м від сучасної денної поверхні були виявлені плями трьох об'єктів: споруда 1 і ями 1, 2. Яма 1 мала складне нашарування і за матеріалом та стратиграфією була розбита ще на одну яму 1a. Її заповнення впритул підходило до заповнення споруди 1 , але вони не були єдиним комплексом. Яма 2 розрізала заповнення споруди 1, чим стратиграфічно підтвердила своє пізніше походження (рис. 3). Під час вибірки заповнення було очевидно, що їх нижні частини запущені вже у передматериковий лесоподібний суглинок.

Споруда 1 розміщалася у кв. $Є$, Ж $-8,9$. Рівень виявлення 186,92 м за Балтійською шкалою висот (далі - БШВ). Орієнтована кутами за сторонами світу. Досліджені розміри: північно-західна стіна (ціла) - 2,2 м; північно-східна (частина) - 0,5 м. Основна частина споруди знаходиться у південній бровці, утвореній через 


\section{АРХЕОЛОГІЯ МІСтА}

Puc. 2. Ситуаційний план розкопів 2016 р.

Рис. 3. Початок робіт на розкопі 1.
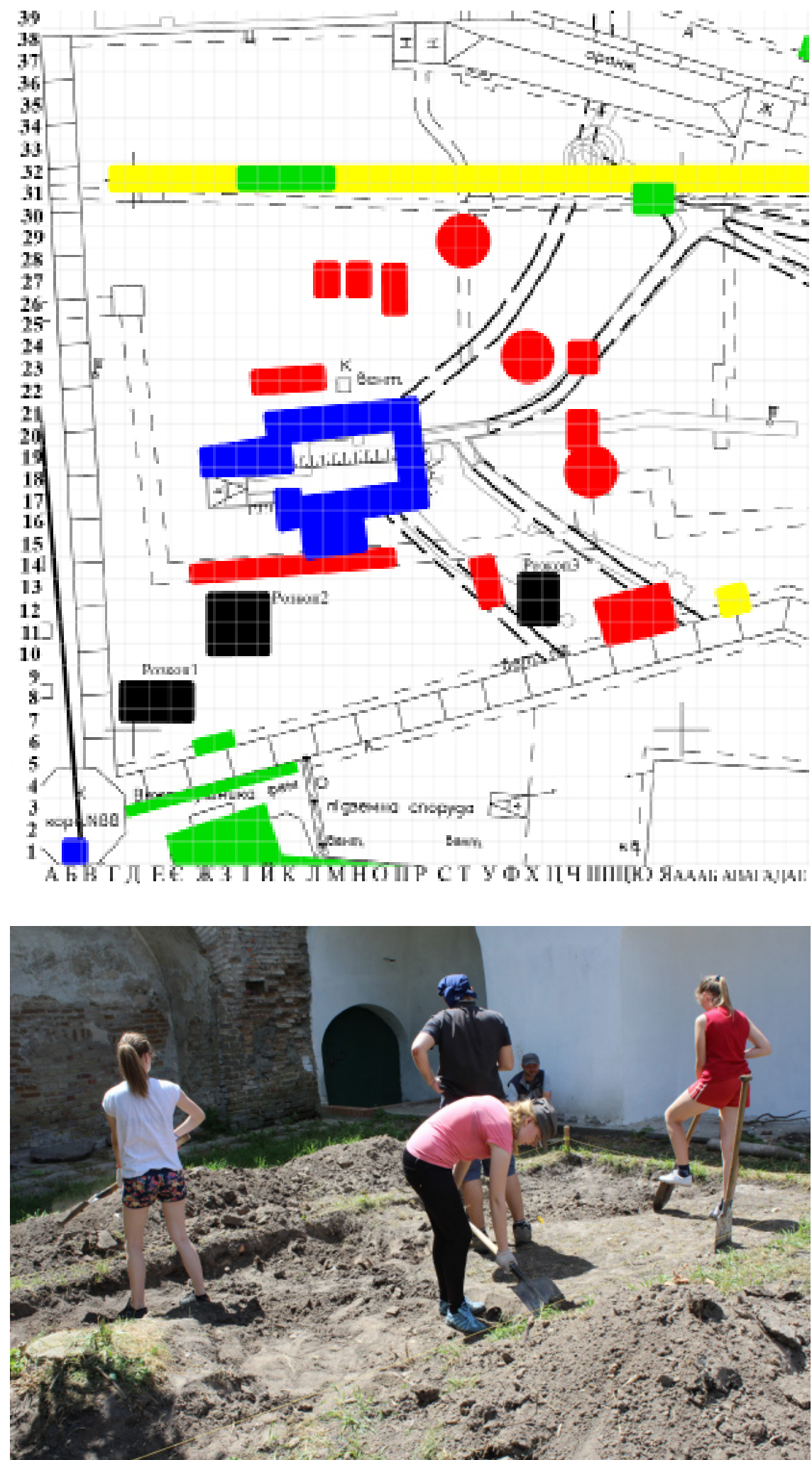

виявлену мережу. У північному та західному кутах зафіксовано стовпові ями діаметром 0,2 м (рис. 4, 5).

У заповненні ям грунт був гумусованим і пухким, вірогідно через згниле дерево, однак саме дерево не збереглося. Стіни рівні, вертикальні. Підлога зафіксована на рівні 186,43 м за БШВ, рівна, крім ділянки біля північного кута - невелике аморфне заглиблення. Заповнення споруди - слабогумусований суглинок темно-сірого кольору. 
Puc. 4. План розкопу 1.

Рuc. 5. Споруда 1, фото.

\footnotetext{
3 Тараненко, С. П., Зажигалов, О. В., Балакін, С. А., Фінадоріна, Д. В., Мисько, Ю.В. (2016).

Звіт про результати археологічних досліджень на території Національного Києво-Печерського історико-культурного заповідника у 2016 р. НА IA НАН України.
}
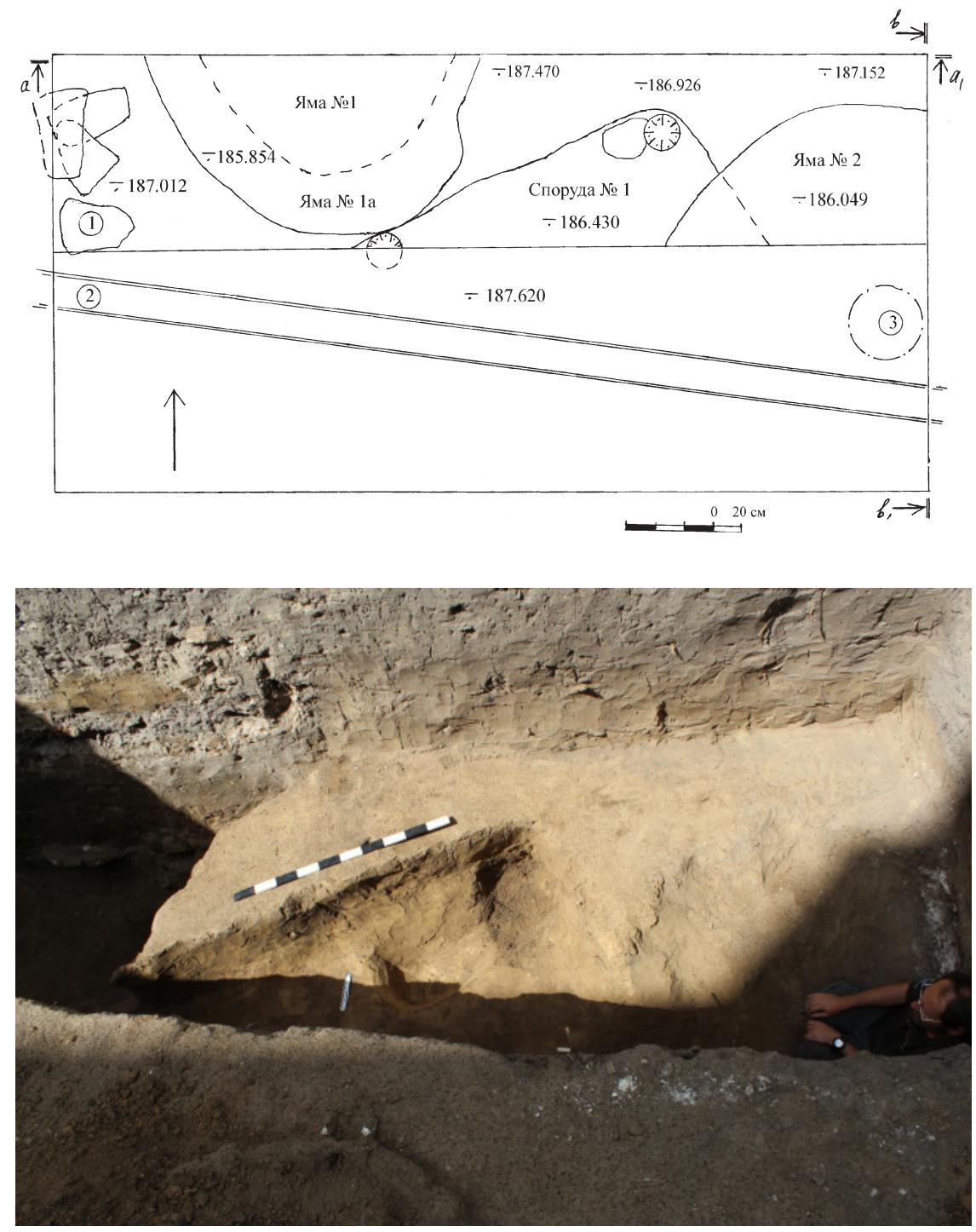

Споруда 1 мала каркасно-стовпову конструкцію i, напевне, була господарського призначення. Хоча досліджена невелика iï частина, але невеликі розміри і відсутність навіть дрібних даних про опалювальну споруду підтверджують наше припущення. За матеріалом та стратиграфією їі можна датувати XVII ст. ${ }^{3}$

Під час досліджень споруди 1 проведено забір біологічних матеріалів дрібних розмірів. 3 цією метою профільтровано частину заповнення споруди, що значно підвищило інформативність археологічних студій.

\section{Матеріали та методи дослідження}

Невід'ємною складовою сучасних археологічних досліджень є використання різноманітних методів природничих наук в археології. Передусім результати аналізів такими методами суттєво поповнюють дані про «природну» складову життя та побуту стародавнього населення. Їхня достатня кількість за належної якості цілком може скласти основу для проведення самостійного наукового дослідження, спрямованого на часткову або й повну реконструкцію палеоекології мікрорегіону пам'ятки. Цілеспрямоване забезпечення забору біологічних зразків на сучасному рівні розвитку методів 
${ }^{4}$ Детально про історію застосування методів див.: Горбаненко, С. А. (2016). Флотація й промивання як методи археологічних досліджень: реалії й перспективи.

Колекиії Наукових фондів IА НАН Украӥни. Проблеми та відкриття. К. (Серія: Археологія і давня історія України, Вип. 1 (18)).

${ }^{5}$ Див. напр.: Янушевич, 3. В. (1976). Культурные растения Юго-Запада СССР по палеоботаническим исследованиям. Кишинев: Штиинца; Ее же (1986). Культурные растения Северного Причерноморья: палеоэтноботанические исследования. Кишинев: Штиинца; Горбаненко, С. А., Пашкевич, Г. О. (2010). Землеробство давніх слов'ян (кінець I тис. до н. е. І тис. н. е.). Київ:

Академперіодика; тощо.

${ }^{6}$ Сукачев, В. Н. (1940). Определитель древесных пород. Москва;

Гаммерман, А. Ф., Никитин, А. А., Николаева, Т. Л. (1946). Определитель древесин по микроскопическим признакам с альбомом микрофотографий. М.; Л.; Вихров, В. Е. (1959). Диагностические признаки древесины главнейших лесохозяйственных и лесопромышленных пород СССР. Москва: б. и. польових археологічних досліджень не лише можливе, але й з огляду на сказане вище, необхідне. Саме для такого забезпечення існують методи флотації й промивання грунту. Флотація (буквально - плавання на поверхні води) - процес розділення матеріалу на легку й важку фракції. Промивання - процес розділення матеріалу на розчинну й нерозчинну фракції ${ }^{4}$.

Ці методи, поруч 3 «класичними», були застосовані також і в ході археологічних досліджень на території Києво-Печерської лаври у 2016 р. Предметом пошуку й дослідження стали рештки біологічного походження зі споруди 1, розкопу 1. У ході археологічних досліджень відбувався забір зразків, до яких належать рештки рослин (зернівки культурних рослин, деревне вугілля) i тварин (кістки і луска риб, кістки птахів і ссавців). Остеологічні матеріали отримано двома способами: цілі та фрагментовані кістки великого розміру (від 2 см і більше) виявлені у ході класичних археологічних досліджень; дрібніші рештки тварин, а також усі ботанічні матеріали відібрано у результаті фільтрації частини заповнення споруди 1 (див. нижче). Усі остеологічні матеріали відповідно до їх систематичної належності (залежно від класу) надійшли на визначення фахівцям.

Для досліджень було відібрано зразок грунту об'ємом близь-

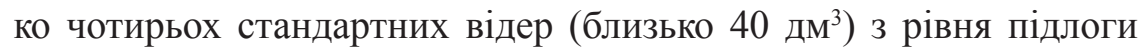
споруди. Надалі їх було розділено на фракції різними методами. Завдяки специфіці грунту (дрібнозернистості) стало можливим часткове просіювання, для чого використано антимоскітну сітку 3 розміром комірок близько 1 мм. Залежно від зволоженості таким чином відсіювалося близько 15-20 \% загального об’єму зразка. Решта грунту надходила для послідовної флотації та промивання (рис. 6-8). За допомогою флотації (забір легкої фракції з поверхні води) ведеться відбір органічних решток рослинного походження (вуглики дерева, карбонізовані зернівки й насіння культурних рослин і бур'янів). Завдяки промиванню можна отримати рештки риб, які мають невеликі розміри (луска, покривні кістки черепа тощо) (рис. 9). Промивання також проведено з використанням антимоскітної сітки. Надалі фракція, що залишилася, перебрана вручну.

Палеоботанічні дані. У результаті флотації частини заповнення споруди 1 на рівні підлоги отримано палеоботанічні макрорештки: палеоетноботанічні (зернівки культурних рослин) й антракологічні (вуглики дерев). Палеоетноботанічний матеріал визначено за морфологічними ознаками за допомогою збільшувальної оптичної техніки; визначення C.А. Горбаненка. Види рослин встановлено завдяки їх порівнянню 3 раніше визначеними зразками, а також широким колом публікацій на цю тему ${ }^{5}$ Породи дерева визначено за мікроструктурою в трьох розрізах: поперечному, радіальному і тангенціальному. Визначники деревини 6 були використані для характеристики отриманих результатів; визначення М.С. Сергєєвої.

Археозоологічні дані. У результаті класичних археологічних досліджень, а також промивання грунту отримано численні рештки тварин (променеперих риб, птахів і ссавців). Визначення систематичної належності іхтіологічного матеріалу проводилися автором 

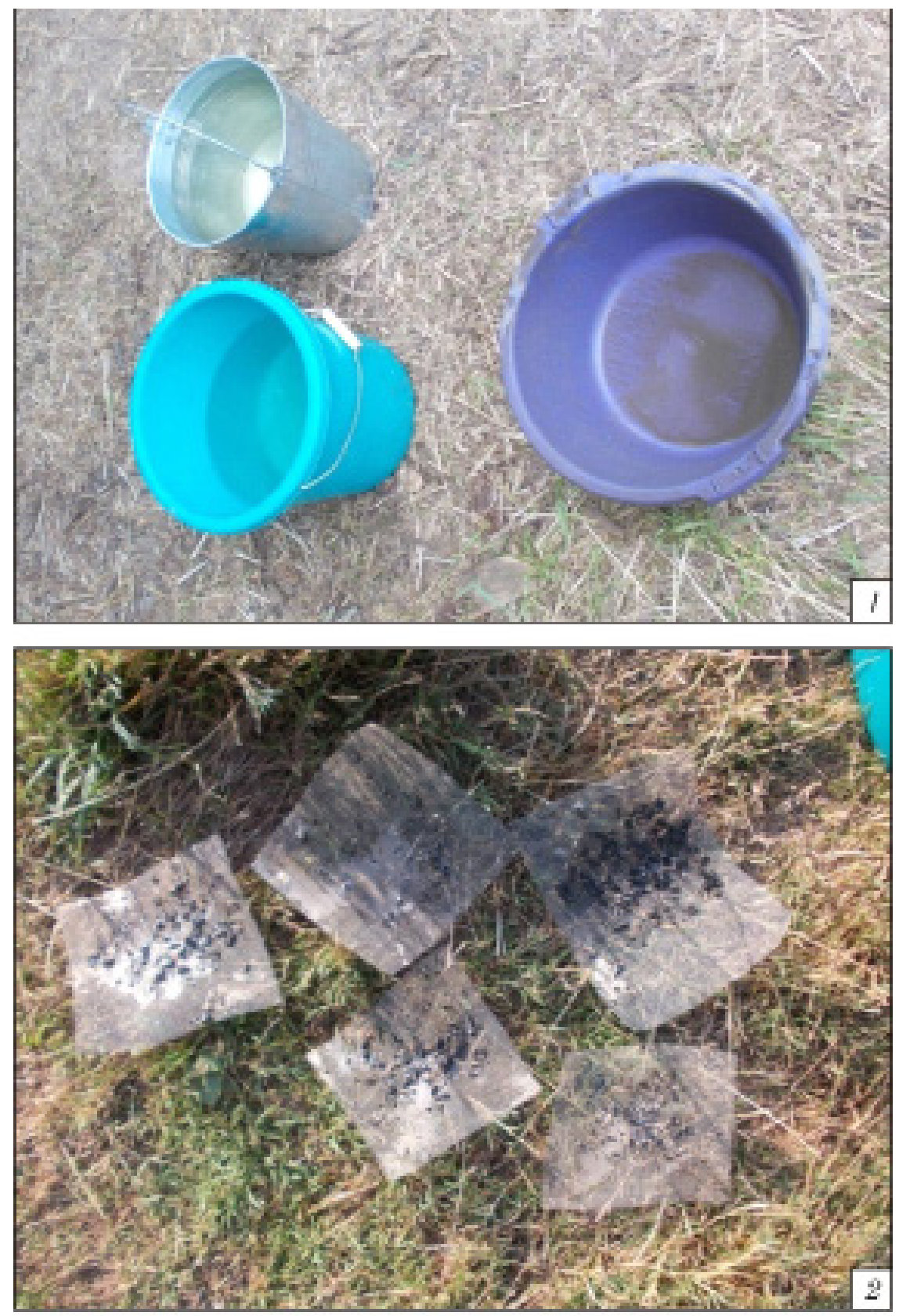

Рис. 6. Знаряддя, необхідні для флотації й промивання: 1 - відра й таз;

2 - невеликі сіточки; 3 - антимоскітна сітка.

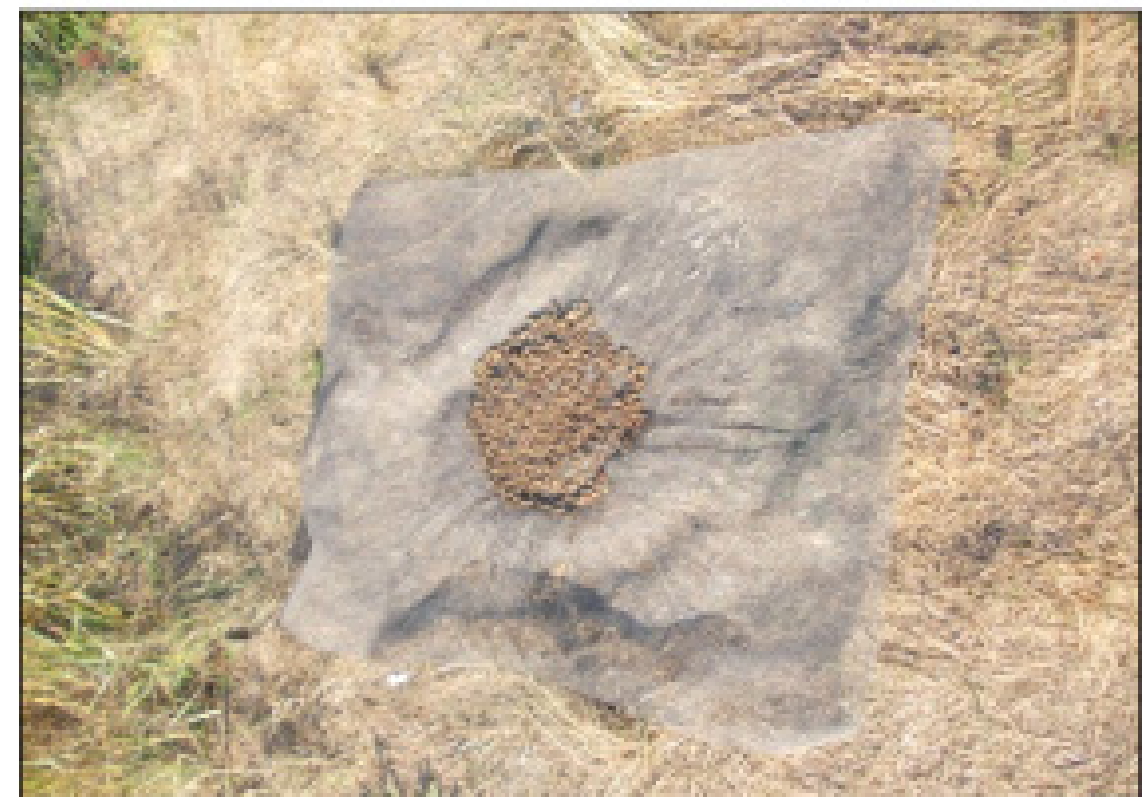




\section{АРХЕОЛОГІЯ МІстА}

Рис. 7. Флотація, робочий момент.

Рис. 8. Промивання, робочі моменти.
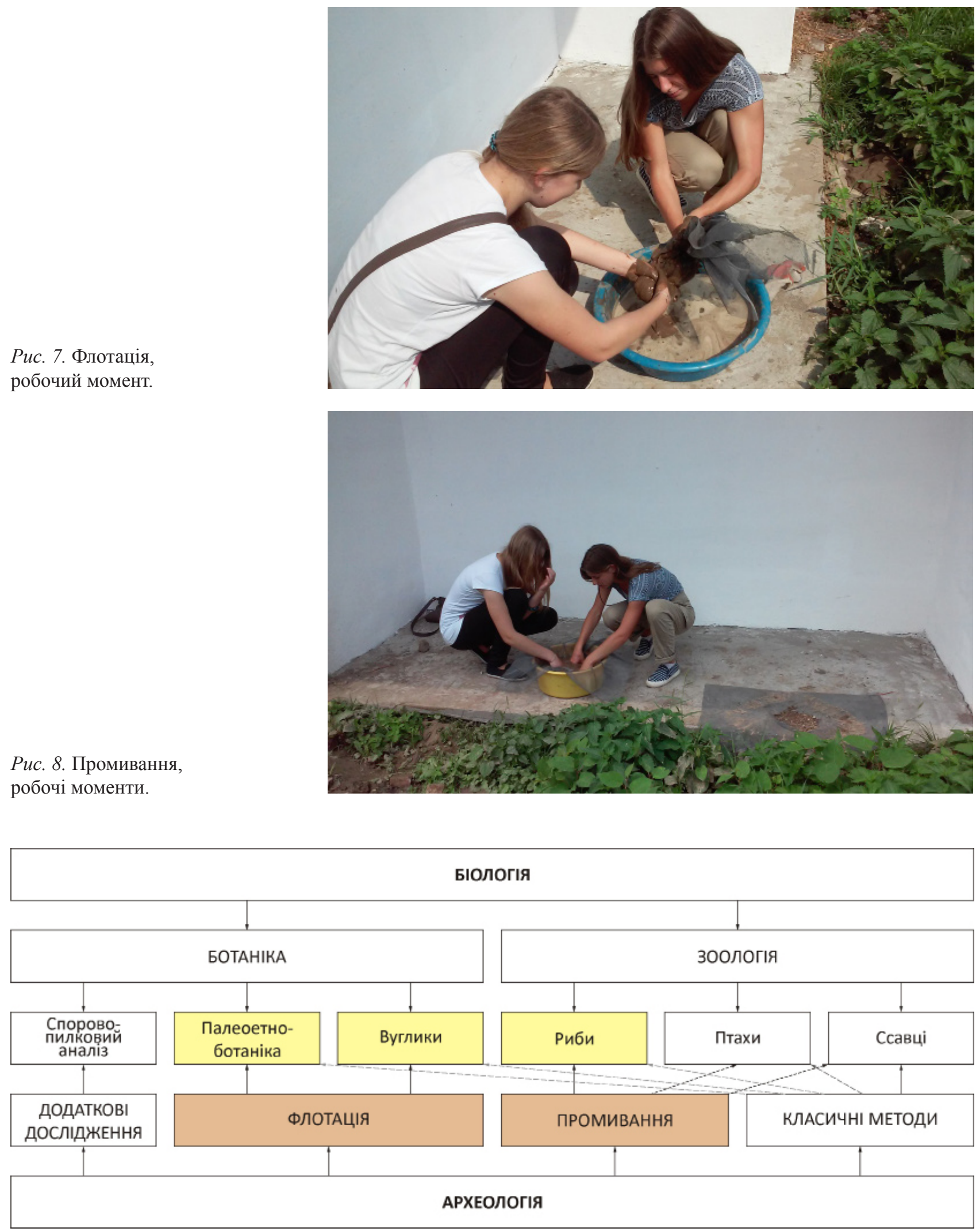

Pис. 9. Можливості

отримання біоматеріалів

у ході археологічних

досліджень поселенських

пам'яток різними методами

забору зразків. Штриховою

лінією вказаний ненадійний /

необов'язковий зв'язок. 
${ }^{7}$ Галкин, Г. Г. (1958).

Атлас чешуи пресноводных костистых рыб. Известия Всесоюзного НИИ озерного и речного рыбного хозяйства, Т. 46; Лебедев, В. Д. (1960). Пресноводная четвертичная ихтиофауна Европейской части СССР. Москва: Московский государственный университет.

${ }^{8}$ Мовчан, Ю. В. (2011). Риби України (визначник-довідник). Київ: Золоті ворота.

${ }^{9}$ Lepiksaar, J. (1994). Introduction to osteology of fishes for paleozoologists. Göteborg.

${ }^{10}$ Radu, V. (2005). Atlas for the identification of bony fish bones from archaeological sites. Bucureşti: Contrast.

${ }^{11}$ Лебедев, В. Д. Указ. соч.

12 Брюзгин, В. Л. (1969). Методы изучения роста рыб по чешуе, костям и отолитам. Київ: Наукова думка.

${ }^{13}$ Driesch, A. von den. (1976). A guide to the measurement of animal bones from archaeological sites. Peabody Museum Bulletin, Bull. 1. за загальноприйнятою методикою ${ }^{7}$ шляхом порівняння кісткових фрагментів і луски з екземплярами сучасних риб із використанням іхтіологічних колекцій Національного науково-природничого музею (далі - ННПМ) НАН України; визначення О.М. Ковальчука. Автором прийнята чинна іхтіологічна систематика ${ }^{8}$. Найменування елементів скелета узгоджені з номенклатурою Й. Лепіксаара ${ }^{9}$ i В. Раду ${ }^{10}$. Вимірювання зроблені штангенциркулем 3 точністю до 0,1 мм. Для встановлення розмірів тіла риб складалася пропорція, куди підставлялися відомості про розмір ідентичних кісток досліджуваної і сучасної риб ${ }^{11}$. Інформацію про співвідношення розмірів кісток і маси тіла риб отримано на підставі значень морфометричних параметрів екземплярів із порівняльних колекцій ${ }^{12}$. Індивідуальний вік особин встановлено за річними кільцями на лусці та хребцях.

Рештки птахів визначали з використанням остеологічної колекції відділу палеонтології ННПМ НАН України. Проміри проводили за існуючою методикою ${ }^{13}$; визначення Л.В. Горобияя.

Теріологічний матеріал опрацьований 3 використанням порівняльної остеологічної колекції сучасних ссавців відділу палеонтології ННПМ НАН України; визначення П.В. Пучкова. Досліджувані кістки ссавців складали групу кухонних решток. Археозоологічний матеріал з місця розкопок 2016 р. на території Лаври зберігається у фондах ННПМ.

\section{Отримані результати}

\section{1. Палеоботанічні матеріали}

\section{1. Палеоетноботанічні рештки}

Виявлено чотири зернівки культурних рослин:

2 зернобобові - вики ервілії (Vicia ervilia);

1 зернівка проса (Panicum miliaceum), очищеного від плівок пшона;

1 зернівка культурної рослини (Cerealia), яка не може бути визначена у зв’ язку з незадовільною збереженістю (зернівка зруйнована).

Таким чином, зважаючи на надзвичайно малу насиченість проби палеоетноботанічними матеріалами, споруда 1 не може стосуватися ні зберігання, ні приготування їжі рослинного походження, а незначні включення слід визнати випадковим занесенням. Однак, на нашу думку, вони можуть вказувати на певний асортимент в раціоні, можливо, каш, що слугували гарнірами або й основною стравою у пости.

На визначення надійшло 14 зразків дрібного вугілля:

сосна (Pinus sp.) - 7;

дуб (Quercus sp.) - 1;

широколистяні - 3;

не визначено - 3 .

Усього визначено до рівня роду 8 екземплярів вугілля. Три зразки належали до широколистяних дерев, проте їхня родова належність не встановлена через невеликі розміри вугликів. Серед проаналізованих зразків репрезентована тільки стигла деревина 
${ }^{14}$ Сергєєва, М., Івакін, В., Тараненко, С., Бібіков, Д., Зоценко, І. (2014). Археологічні дослідження у Київському Гостинному дворі. Київ: б. в. (від стовбурів дерев). Визначене вугілля належить породам, характерним для мішаних і широколистяних лісів досліджуваного регіону. Деревина сосни і дуба належала до основних видів ділової деревини 3 широким діапазоном використання, що підтверджують наші спостереження археологічного дерева на різних археологічних пам'ятках, переважно давньоруського часу. Прикладом синхронного матеріалу є дерев'яні конструкції та вироби з сосни, виявлені під час досліджень Гостинного двору в Києві (весло, частина бондарного посуду) ${ }^{14}$. Дрібні розміри вугілля не дають можливості його точної інтерпретації. Значення роботи з дрібним вугіллям полягає насамперед в отриманні додаткових даних для подальшої характеристики сировинної бази деревообробки Києва у різні часи.

\section{2. Археозоологічні матеріали}

\section{1. Іхтіологічні рештки}

На визначення були передані 77 решток риб. Усі рештки належать променеперим рибам (Actinopterygii). 3 них до виду визначено 31 $(40 \%)$.

Осетер російський Acipenser gueldenstaedtii. Цьому виду належить одна досить велика і частково зруйнована кістка (права dermosupraoccipitale), довжина якої становить 73,7 мм. На кістці є дві глибокі насічки, залишені ножем. Встановити розміри і масу тіла риби неможливо у зв'язку з відсутністю порівняльних даних. Кістка належала крупній дорослій особині.

Лящ звичайний Abramis brama. У зборах є одна практично ціла ліва глоткова кістка (ceratobranchiale) зі зруйнованими глотковими зубами, фрагмент такої самої кістки з двома глотковими зубами (dentes pharyngiales) і два фрагменти ceratobranchiale з одним глотковим зубом кожна. Реконструйована довжина тіла риби становила 44 см, маса - 870 г. Ймовірніше, всі рештки належать одній особині, але були фрагментовані.

Коропові риби невизначені Cyprinidae indet. До групи решток, умовно зарахованих до коропових, належить 34 декальцинованих і фрагментованих лускових пластинки. У зв'язку з цим визначити їх точніше неможливо.

Щука звичайна Esox lucius. Цей вид представлений у зборах трьома хребцями (з них два черевні та один хвостовий). Їхній діаметр становить 4,0; 5,9 і 7,4 мм. С висока ймовірність того, що вони належали двом особинам, довжина тіла яких становила $38 \mathrm{i}$ 49 см, маса - 570 і 720 г відповідно. Індивідуальний вік риб досягав трьох років, тобто кістки належали дорослим статевозрілим, але порівняно невеликим особинам.

Окунь річковий Perca fluviatilis. У зборах є дуже фрагментовані одиничні кістки окуня (1 praemaxillare, 1 dentale, 1 interoperculare), за якими неможливо встановити розміри і масу тіла риб. Також наявні 19 лускових пластинок, що належали особинам 3-5 років (більшість - 4-річним рибам).

Костисті риби невизначені Teleostei indet. Частина кісткових фрагментів (один промінь плавця, дві невеликі покривні кістки че- 
${ }^{15}$ Мельник, О. П. (2015). Результати визначення видової приналежності скелетованих решток тварин з розкопок 2015 року по східній секції корпусу № 4 Києво-Печерської Лаври.

${ }^{16}$ Мовчан, Ю. В. Вказ. праця.

${ }^{17}$ Мовчан, Ю. В. Вказ. праця.

${ }^{18}$ Брюзгина (Уманская), А. С. (1975). Позднеантропогеновые птицы Украины и смежных территорий (преимущественно по материалам из археологических памятников): Автореф. дис. ... канд. биол. наук. Киев. репа, 9 уламків ребер), отриманих у ході розкопок і подальшої обробки проби, є недіагностичними і їхня систематична належність не може бути встановлена.

За результатами досліджень 2015 р. матеріалів зі східної секції корпусу 4 КПЛ (період XVII-XVIII ст.) також було зафіксовано рештки щуки до 1 кг; на відміну від цьогорічних матеріалів, виявлено й рештки сома ${ }^{15}$.

Усі види риб, установлені в результаті аналізу (за винятком хіба що осетра російського), входять до складу місцевої іхтіофауни, тобто є досить звичайними у водоймах басейну Середнього Дніпра. Лящ - озерно-річкова жила риба слабопроточних водойм і водотоків, живиться безхребетними тваринами. Щука типовий хижак - віддає перевагу місцям 3 повільною течією, прохолодною, насиченою киснем водою і розвинутою підводною рослинністю. Окунь - прісноводна зграйна придонна хижа риба, яка також частіше трапляється на ділянках корінного русла з чистою, добре аерованою водою, де тримається поблизу або серед заростів рослинності, затоплених дерев і корчів ${ }^{16}$. Таким чином, можна припустити, що риби, рештки яких були опрацьовані, добуті або безпосередньо у Дніпрі, або в якійсь із його приток. Наявність кістки крупного осетра свідчить про високий соціальний статус мешканця садиби, який міг дозволити собі купити цей продукт. М'ясо осетрових риб є дуже цінним за смаковими якостями, вважається делікатесом і тому дорого коштувало. 3 іншого боку (хоча це i не суперечить попередньому висновку) можна припустити, що осетри у XVII ст. могли підніматися на нерест вгору по течії Дніпра до широти Києва, де і впіймали одного з них. На сьогодні представники цього виду трапляються у північно-західній частині Чорного моря і лише зрідка заходять у Дніпро і Дністер ${ }^{17}$.

\section{2. Орнітологічні рештки}

На аналіз надійшло шість кісток птахів 3 різних частин скелету. Усі рештки можна визначити до видового рівня. Кістки належать до 2 видів.

Гуска сіра або гуска домашня (Anser anser / Anser anser domestica). Виявлено чотири рештки, що належали щонайменше двом дорослим особинам гусей: грудина, права лопатка, дві правих плечових кістки. Депозитарні номери NMNHU-P AZ-6249, AZ-6250, AZ-6251, AZ-6252.

За морфологічними ознаками, домашня гуска і дика форма (гуска сіра) у більшості випадків не відрізняються [Брюзгина, $1975]^{18}$. За морфометричними показниками, усі кістки перебувають у діапазоні, властивому як дикій, так і домашній формі. Найвірогідніше, виявлені кістки належали домашній птиці, оскільки для XVI-XVIII ст. помітна тенденція до переважання частки домашніх птахів над мисливськими видами.

Курка домашня (Gallus gallus domestica). Дві кістки (грудина і права тібіотарзальна) належали домашній курці, ймовірно одній дорослій особині. Депозитарні номери NMNHU-P AZ-6253, AZ-6254.

Діагональ проксимального кінця тібіотарзальної кістки становить 23,4 мм, ширина - 14,9 мм, товщина діафізу - 6,3 мм. 
${ }^{19}$ Горобець, Л. В. (2015).

Рештки птахів у шарах

XI ст. $з$ території подвір'я

Софії Київської.

Археологічні зошити

з Пересопниці: III наук.

археол. симпоз. «Літописні

міста давньоруської

держави». Пересопниця;

Gorobets, L. V.,

Kovalchuk, O. M.,

Pshenychny, Yu. L. (2016).

Remains of fish and birds

from the Dubno Castle (16th century, Rivne Region, Ukraine).

Studia Biologica,

Vol. 10, no. 1.

${ }^{20}$ Rick, A. M. (1975). Bird medullary bone: a seasonal dating technique for faunal analysts. Bulletin of Canadian Archaeological Association, No. 7.

${ }^{21}$ Мельник, О. П. Вказ. праця.

${ }^{22}$ Gorobets, L. V.,

Kovalchuk, O. M.,

Pshenychny, Yu. L. Op. cit.

${ }^{23}$ Горобець, Л. В. Вказ. праця; Gorobets, L., Kovalchuk, O.

(2016). Birds in the Medieval culture and economy of the East Slavs in the 10-13th cent. AD. Environmental Archaeology: The Journal

of Human Palaeoecology (doi: 10.10 80/14614103. 2016. 1141088).

${ }^{24}$ Горобець, Л. В. (2016). Дослідження решток птахів. Археологічні дослідження в Україні 2015. Київ.

${ }^{25}$ Мельник, О. П. Вказ. праця.
Ці показники близькі до розмірів сучасної безпородної курки та трохи більші, ніж у курей, кістки яких знайдені на пам'ятках XIXVI ст. ${ }^{19}$. Медулярна тканина відсутня, отже птах не відкладав яйця принаймні незадовго до смерті ${ }^{20}$. Це може мати два пояснення: 1) птах був півнем; 2) курку спожили взимку.

За результатами досліджень 2015 р. також було зафіксовано рештки цих обох видів; на відміну від цьогорічних матеріалів, виявлено й рештки голуба ${ }^{21}$.

Курка і гуска є типовими представниками птахівництва на території України протягом X-XVIII ст., тоді як, за нашими спостереженнями, рештки качки трапляються вкрай рідко. У X-XIII ст. серед спожитих птахів переважали мисливські види ${ }^{22}$. Роль птахівництва у пізніші часи остаточно не встановлена у зв'язку із малою кількістю остеологічного матеріалу. Але дослідження замку в Дубно (XVI ст.) дають підстави припускати, що приблизно в цей час відбулась зміна в господарчій ролі птахів: домашні види в раціоні почали переважати над мисливськими ${ }^{23}$. Підтвердженням цього є результати аналізу решток у шарах XVII і XVIII ст. 3 Харкова, де взагалі не виявлено мисливських видів птахів (наші дані; розкопки ДП «Слобідська археологічна служба» 2015 та 2016 pp. ${ }^{24}$ ). Рештки, знайдені на території Києво-Печерської лаври, $\epsilon$ ще одним підтвердженням припущення про зменшення ролі мисливських видів птахів. Звичайно, вибірка дуже мала, але навіть вона має значення, оскільки інші дані про рештки птахів на пам'ятках Нового часу в межах України нині майже відсутні.

\section{3. Теріологічні рештки}

Загалом було проаналізовано 17 кісток ссавців з розкопу 2016 р. До виду вдалося визначити 9 із них (53 \%). Рештки, які надійшли на аналіз, належать до трьох видів, що є звичайними представниками свійських тварин.

Бик свійський Bos taurus. Представникові цього виду (мінімальна кількість особин - 2) належать метатарзальна кістка, великогомілкова кістка (дуже мала), фрагмент тазу з acetabulum, копитцева кістка, фрагмент ребра, фрагмент хребця і передкорінний зуб. Рештки, імовірно, належать невеликій молодій корові, на що вказують невеликі розміри і грацильність кісток.

Коза або вівця Capra vel Ovis. У зборах є лопатка, ребро, 1 шийний хребець (атлант), 2 грудних і 2 поперекових хребці, а також частина тазу. Усі ці рештки належать козі або вівці. Мінімальна кількість особин - 2.

Свиня свійська Sus scrofa domestica. Лопатка і великогомілкова кістка належать мінімально одній молодій особині.

Результати досліджень 2015 р. мають доволі значні розбіжності з отриманими у 2016 р.: було встановлено існування кісток поросяти, але незрозуміло, чи то була свійська особина, чи дика. Частина кісток належить оленю, частина - козулі. Один поперековий хребець 3 пошкодженим тілом належить лошаті. За наявним матеріалом вік вказаної особини достеменно встановити неможливо. Однак, чітко зрозуміло, що це молода тварина віком менше 1 року $^{25}$. За описом матеріалів 2015 р. встановлено, що це кухонні рештки. Пояснення таких кардинальних відмінностей поки немає. 
Помітно лише те, що теріологічні рештки зі споруди 1 репрезентують типовий набір м'ясних тварин, а матеріали зі східної секції корпусу № 4 - «екзотичний» (переважно - дикі тварини, об’ єкти полювання). Чи така разюча відмінність вказує на різні смаки, чи на різний спосіб надходження м'ясних продуктів - нині залишається лише здогадуватись.

$* * *$

Таким чином, до раціону власника споруди 1 входили усі типові види їжі рослинного й тваринного походження. Перші представлені одиничними обвугленими макрорештками: викою і просом. Обидва види можуть бути використані для приготування каш або інших страв. Продукти м'ясного походження представлені різноманітними рештками тварин: свійських ссавців (корова, коза / вівця, свиня), домашніх птахів (гуси, кури), а також продуктами риболовлі (осетер російський, лящ звичайний, щука звичайна, окунь річковий, невизначені коропові риби). Отже, тваринна продукція представлена переважно домашніми і найпоширенішими видами (звертаємо увагу на те, що кістки коней у кухонних рештках відсутні) і доповнена рибою. Остання як предмет промислу завжди була (й частково лишається) вагомою підмогою у біогосподарській діяльності.

Досі не вироблено методик, які б уможливили за такими біологічними рештками встановлення співвідношення продуктів різного походження у раціоні людей. Відома нині методика встановлення такого співвідношення стосується лише фізико-хімічного аналізу антропологічних остеологічних решток.

Виявлені породи дерев $є$ типовими представниками місцевої флори здавна і мають найширший спектр використання.

Отримані рештки є результатами біогосподарської діяльності. Зважаючи на історичний контекст, ми схильні розглядати їх як продукти споживання у широкому розумінні. Існує велика ймовірність того, що усі продукти харчування (а можливо й деревина - для палива) не є результатом праці людини, якій належала споруда 1 , а залишені рештки є відображенням споживчих уподобань. Сподіваємося, що результати визначень природничими методами стануть у нагоді історикам, які за писемними джерелами займаються вивченням давнього побуту загалом і кухнею зокрема, адже це достовірні докази використання тих чи інших продуктів харчування.

Продовження забору біологічних зразків з розкопок на території Києво-Печерської лаври у ході майбутніх археологічних досліджень сприятиме накопиченню визначень і переходу до якісного аналізу.

\section{REFERENCES}

Balakin, S. A., Zazhygalov, O. V., Finadorina, D. V. (2014/[b n.]) Zvit pro rezul'taty arkheolohichnykh doslidzhen' na terytoriyi Natsional'noho Kyyevo-Pechers'koho istoryko-kul'turnoho zapovidnyka u 2014 r. Naukovyy arkhiv Instytutu arkheolohiyi Natsional'noyi akademiyi nauk Ukrayiny (dali-NA IA NAN Ukrayiny).

Bryuzgin, V. L. (1969) Metody izuchenija rosta ryb po cheshue, kostyam i otolytam. Kyiv: Naukova dumka, 188. 
Driesch, A. von den. (1976) A guide to the measurement of animal bones from archaeological sites. Peabody Museum Bulletin, Bull. 1, 102-137.

Galkin, G. G. (1958) Atlas cheshui presnovodnyh kostistyh ryb. Izvestija Vsesojuznogo NYY ozernogo i rechnogo rybnogo khoz'ajstva, T. 46, 1-105.

Gammerman, A. F., Nikitin, A. A., Nikolaeva, T. L. (1946) Opredelitel' drevesin po mikroskopicheskim priznakam s al'bomom mikrofotografij. Moskva; L., 144.

Gorbanenko, S. A. (2016). Flotatsiya y promyvannya yak metody arkheolohichnykh doslidzhen': realiyi y perspektyvy. Kolektsiyi Naukovykh fondiv IA NAN Ukrayiny. Problemy ta vidkryttya. Kyiv, 137-144 (Seriya: Arkheolohiya i davnya istoriya Ukrayiny, Vyp. 1 (18))

Gorbanenko, S. A., Pashkevych, H. O. (2010) Zemlerobstvo davnikh slovjan (kinets' I tys. do n. e. - I tys. n. e.). Kyiv: Akademperiodyka, 316.

Gorobets, L., Kovalchuk, O. (2016) Birds in the Medieval culture and economy of the East Slavs in the $10-13^{\text {th }}$ cent. AD. Environmental Archaeology: The Journal of Human Palaeoecology (doi: 10.1080/14614103.2016.1141088).

Gorobets, L. V., Kovalchuk, O. M., Pshenychny, Yu. L. (2016) Remains of fish and birds from the Dubno Castle ( $16^{\text {th }}$ century, Rivne Region, Ukraine). Studia Biologica, Vol. 10, no. 1, 111-122.

Horobets', L. V. (2015) Reshtky ptakhiv u sharakh XI st. z terytoriyi podvirja Sofiyi Kyyivs'koyi. Arkheolohichni zoshyty z Peresopnytsi: III nauk. arkheol. sympoz. "Litopysni mista davn'orus 'koyi derzhavy». Peresopnytsya, 14-19.

Horobets', L. V. (2016). Doslidzhennya reshtok ptakhiv. Arkheolohichni doslidzhennya $v$ Ukrayini 2015. Kyyiv, 260-261.

Lebedev, V. D. (1960) Presnovodnaja chetvertichnaja ikhtiofauna Evropejskoj chasty SSSR. Moskva: Moskovskij gosudarstvennyj universitet, 1960, 404.

Lepiksaar, J. (1994) Introduction to osteology of fishes for paleozoologists. Göteborg, 96.

Mel'nyk, O. P. (2015) Rezul'taty vyznachennya vydovoyi prynalezhnosti skeletovanykh reshtok tvaryn z rozkopok 2015 roku po skhidniy sektsiyi korpusu \# 4 Kyyevo-Pechers'koyi Lavry. Kyiv, 2.

Movchan, Yu. V. (2011) Ryby Ukrayiny (vyznachnyk-dovidnyk). Kyiv: Zoloti vorota, 444.

Radu, V. (2005) Atlas for the identification of bony fish bones from archaeological sites. Bucureşti: Contrast, 80.

Rick, A. M. (1975) Bird medullary bone: a seasonal dating technique for faunal analysts. Bulletin of Canadian Archaeological Association, No. 7, 183-190.

Serhyeyeva, M., Ivakin, V., Taranenko, S., Bibikov, D., Zotsenko, I. (2014) Arkheolohichni doslidzhennya u Kyyivs'komu Hostynnomu dvori. Kyiv, 100.

Sukachev, V. N. (1940) Opredelytel' drevesnykh porod. Moskva, 497.

Taranenko, S. P., Mys'ko, Yu. V., Zazhyhalov, O. V., Balakin, S. A. (2016) Stvorennya arkheolohichnoyi karty Natsional'noho Kyyevo-Pechers'koho istoryko-kul'turnoho zapovidnyka. Tserkva-nauka-suspil'stvo pytannya vzayemodiyi: Materialy Chotyrnadtsyatoyi Mizhnar. nauk. konf. (25 travnya - 3 chervnya 2016 r.). Kyiv, 2016, 30-32.

Taranenko, S. P., Zazhyhalov, O. V., Balakin, S. A., Finadorina, D. V. (2016) Zvit pro rezul'taty arkheolohichnykh doslidzhen' na terytoriyi Natsional'noho Kyyevo-Pechers'koho istoryko-kul'turnoho zapovidnyka u 2016 r. NA IA NAN Ukrayiny.

Vihrov, V. E. (1959) Diagnosticheskije priznaki drevesiny glavnejshih lesohoz'ajstvennyh i lesopromyshlennyh porod SSSR. Moskva, 132.

Yanushevich, Z. V. (1976) Kul'turnyje rastenija Yugo-Zapada SSSR po pa-leobotanicheskim issledovanijam. Kishinev: Shtiintsa, 214.

Yanushevich, Z. V. (1986) Kul'turnyje rastenija Severnogo Prichernomor'ja: paleoetnobotanicheskije issledovanija. Kishinev: Shtiintsa, 90. 
Сергей Тараненко, Сергей Горбаненко, Александр Ковальчук, Леонид Горобец, Марина Сергеева, Павел Пучков

\section{КОМПЛЕКСНЫЕ БИОАРХЕОЛОГИЧЕСКИЕ ИССЛЕДОВАНИЯ МАТЕРИАЛОВ ИЗ РАСКОПОК НА ТЕРРИТОРИИ КИЕВО-ПЕЧЕРСКОГО ЗАПОВЕДНИКА В 2016 г.}

В публикации представлены результаты комплексных биоархеологических определений из археологических исследований 2016 г. сооружения 1 раскопа 1 Национального Киево-Печерского историко-культурного заповедника.

Благодаря методу флотации получено незначительное количество палеоэтноботанических материалов (зернобобовые, также просо) и антракологических остатков (угольков сосны, а также дуба и неопределенных широколиственных). Благодаря промывке почвы получены остатки рыб (осетр российский, лещ обыкновенный, шука обыкновенная, окунь речной). Классическим способом получены более крупные остатки млекопитающих (бык домашний, овцуа / коза, свинья), а такюе птии (гусь и куриияа домашние).

Таким образом, получены данные, характеризующче раџион владельца сооружения 1. Однако, на данном этапе невозможно указать удельный вес тех или иных продуктов питания в раичиое. Можно лишь констатировать, что продукты были достаточно обыденными, а их появление следует связать не с самой хозяйственной деятельностью по их вырашчиванию, а с приобретением готовых продуктов.

Ключевые слова: Киево-Печерская лавра, флотащия, промывка, палеоботаника, археозоология.

Serhiy Taranenko, Serhiy Gorbanenko, Oleksandr Kovalchuk, Leonid Gorobets, Maryna Sergeyeva, Pavlo Putshkov

\section{INTEGRATED BIOARCHAEOLOGICAL RESEARCH DURING THE EXCAVATIONS IN KYIV-PECHERSK RESERVE IN 2016}

The results of complex bio-archaeological definitions from archaeological research in 2016 (excavation 1, construction 1) on the territory of the National Kyiv-Pechersk Historical and Cultural Reserve are represented in this paper.

Using the method of flotation, a small amount of palaeoethnobotanical material (leguminous plants, and millet) as well as anthracological remains (charcoal of pine and oak, indeterminate deciduous trees) was obtained. Using the screen-washing of the soil, fish remains were obtained; these bones are belonged to Russian sturgeon, common bream, northern pike and common perch. The bigger remains of mammals (cattle, sheep or goat, and pig) and birds (domestic goose and chicken) were obtained through the 'classic' way (i.e., during the excavations).

Thus, the obtained data characterizing the diet of the holder of the construction 1 were obtained. However, it is not possible to specify the proportion of specific products in this diet at this stage of our research. It can be only concluded that they were quite ordinary, so its appearance should be caused by the acquisition of finished food; such result was probably not associated with the economic activity of cultivation of these products.

Keywords: Kiev-Pechersk lavra, flotation, screen-washing, palaeobotany, archaeozoology. 